\title{
Review on the Recent Developments of Photovoltaic Thermal (PV/T) and Proton Exchange Membrane Fuel Cell (PEMFC) Based Hybrid System
}

\author{
Afzam Zulkepli ${ }^{1}$, Hassan Ibrahim ${ }^{1}$, Azri Alias ${ }^{1}$, Zafri Azran ${ }^{2}$, Firdaus Basrawi $^{1}$ \\ ${ }^{1}$ ESFG, Faculty of Mechanical Engineering, UMP Pekan, Pahang, Malaysia \\ ${ }^{2}$ Kuliyyah of Allied HealthSciences, IIUM, Kuantan, Pahang, Malaysia
}

\begin{abstract}
Photovoltaic Thermal (PV/T) system emerged as one of the convenient type of renewable energy system acquire the ability to generate power and thermal energy in the absence of moving parts. However, the power output of $\mathrm{PV} / \mathrm{T}$ is intermittent due to dependency on solar irradiation condition. Furthermore, its efficiency decreases because of cells instability at high temperature. On the other hand, fuel cell co-generation system (CGS) is another technology that can generate power and heat simultaneously. Integration of PV/T and fuel cell CGS could enhance the reliability and sustainability of both systems as well as increasing the overall system performance. Hence, this paper intended to present the parameters that affect performance of PV/T and Proton Exchange Membrane Fuel Cell (PEMFC) CGS. Moreover, recent developments on PV/T-fuel cell hybrid system are also presented. Based on literates, mass flow rate of moving fluid in PV/T was found to affect the system efficiency. For the PEMFC, when the heat is utilized, the system performance can be increased where the heat efficiency is similar to electrical efficiency which is about $50 \%$. Recent developments of hybrid PV/T and fuel cell show that most of the studies only focus on the power generation of the system. There are less study on the both power and heat utilization which is indeed necessary in future development in term of operation strategy, optimization of size, and operation algorithm.
\end{abstract}

\section{Introduction}

Continuous concerns on global and local environmental problems and depletion of conventional energy source have encouraged the transition towards renewable energy resources. Research on green energy power generation system continues to gather momentum when the remaining reserve of oil and gas rapidly dwindles as the world population increases. Among the renewable energy power generation systems, Fuel cell and $\mathrm{PV} / \mathrm{T}$ are promising systems as both are clean and can generate electrical and heat simultaneously. Various studies have been developed to penetrate these systems on residential application in either grid tied or standalone distributed generation. Furthermore, these two technologies also play the key role in the currently developing smart grid system that allows two-way connection between utilities and consumers[1].

Hybrid power systems combine two or more sources of renewable energy into one system which can be merged or differentiated through different configuration or architecture[2]. Electrical output of a single renewable energy source is limited and is not consistent but due to their complementarities the integration could overcome the drawbacks. The purpose of a hybrid system is to produce as much energy from renewable energy sources to ensure load demand and to reduce the dependency on

\footnotetext{
a Corresponding author: mfirdausb@ump.edu.my
}

only one system which has intermittent output power. The intermittent output power of photovoltaic due do the dependency on weather circumstances can be covered by merging photovoltaic system with other renewable source such as fuel cell. Fuel cell system is not dependent on solar radiation, the technology could be a backup power generator for photovoltaic during the night or when power output of photovoltaic is deficient. Fuel cell system is a promising power generation technology to provide energy for rural areas when there is no access to grid system[3]. Furthermore, using hydrogen as the reactant makes the technology environmentally clean and noiseless[4,5]. This paper presents the review of parameters that affect both $\mathrm{PV} / \mathrm{T}$ and PEMFC CGS. Furthermore, recent developments on PV/T-PEMFC based hybrid system are also presented.

\section{Photovoltaic Thermal (PV/T)}

PV/T system consists of two main components, namely; photovoltaic panel which generates electricity from solar energy through photoelectric effect and solar thermal collector which absorbs solar radiation and transforms the energy into thermal energy[6]. The absorber plate as shown in Fig.1 underneath the solar cell has twofold functions which are to cool the solar cell and to collect 
the heat energy from solar irradiation. The idea of merging these two technologies is because the increase of solar cell temperature will decrease the efficiency of photovoltaic system proportionally. In order to resolve this problem, combining solar collector with photovoltaic will sustain the temperature of the solar cell at optimal range, thus, increasing the efficiency of photovoltaic. On the other hand, thermal energy can be used for heating and thus increase the overall system efficiency[7].

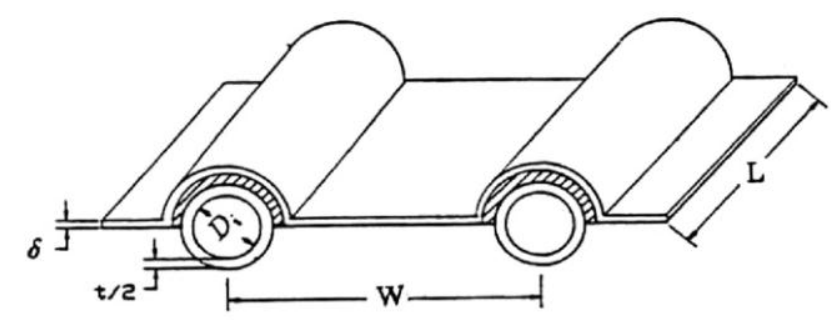

Figure 1. Absorber plate of $\mathrm{PV} / \mathrm{T}[8]$

PV/T system can be classified by the different type of coolant used, namely: air, water and refrigerant. In the previous study as shown in table 1 , refrigerant coolant type has the highest efficiency which is $56 \%-74 \%$. Based on physical design, it can be distinguished by flat plate type, concentrated or building integrated type.

Table 1. PV/T efficiency with different type of coolant.[9,10,11]

\begin{tabular}{lc}
\hline PV/T models & Average efficiency (\%) \\
\hline Air based PV/T type & $24-47$ \\
water based PV/T type & $33-59$ \\
refrigerant PV/T type & $56-74$
\end{tabular}

\subsection{Controlled parameters on PV/T}

\subsubsection{Solar cell}

The material of photovoltaic cell provides a big impact on the overall performance of $\mathrm{PV} / \mathrm{T}$. This type of solar cell has been comprehensively reviewed by Moradi et.al [12]. Multijunction type of solar cell is found to have the highest efficiency with $32 \%$ and currently the most broadly used is single crystalline silicone solar cell.

\subsubsection{Packing factor}

The study made by Vats et.al [13] showed that the increase of packing factor is not always proportional with the efficiency of the system. An optimal packing factor is crucial for the $\mathrm{PV} / \mathrm{T}$ performance as the high value of packing factor will cause the increase of solar cell

\footnotetext{
${ }^{a}$ Corresponding author: mfirdausb@ump.edu.my
}

temperature and thus decrease the electrical efficiency. In contra, low value of packing factor will reduce the solar radiation absorber area and also leads to low electrical efficiency.

\subsubsection{Mass flow rate}

As the efficiency of photovoltaic decreases when the temperature of solar cell increases, a good convection heat flow is vital by means of mass flow rate of the moving fluid. The moving fluid underneath the solar cell can be naturally moved [14] or by force from a pump [15].The mass flow rate is influenced by the type of material used for the circulating fluid, its velocity, and also thegeometry of the PV/T system. The mass flow rate used in previous studies range from $0.01 \mathrm{~kg} / \mathrm{s}$ to $0.3182 \mathrm{~kg} / \mathrm{s}$ as stated by Shahsavar and Ameri[16].

\subsubsection{Absorber design}

Ibrahim et.al [17] has conducted a study on several absorber design such as oscillatory, direct flow, modified serpentine-parallel flow, spiral flow, serpentine flow, parallel-serpentine flow and web flow. Spiral flow design showed the best result with total efficiency of $68 \%$.

\subsubsection{PV/T configuration}

The configuration of PV/T also affects the performance of the system. A study on various configurations had been carried out by Tiwari and Soda [18] who investigate the glazed and unglazed PV/T. The efficiency of all the configurations were compared and the glazed without tedlar showed the best performance. Dubey and Tiwari [19] investigated the performance of solar flat-plate collector partially covered using theoretical modeling. The result showed that partially covered collector is better when the main load is thermal and for fully covered collector, it is greater when the main load is electricity. An explicit dynamic model has been introduced by Chow [20] to investigate the performance of single-glazed sheet-and-tube collector. Zondag et.al [21] compared the performance of separately photovoltaic and solar collector with combined PV-thermal collector. Combined $\mathrm{PV}$ and solar collector is found to produce more energy than separately installed PV and solar collector.

Various studies have been conducted previously in investigating the parameters that influencing the performance of $\mathrm{PV} / \mathrm{T}$. This result in many aspects should be considered in designing the system. Mass flow rate of $\mathrm{PV} / \mathrm{T}$ was found to affect the system performance because it affects the temperature of the solar cell and also an important factor to be considered in absorbing the heat energy. $\mathrm{PV} / \mathrm{T}$ system itself is however not sustainable as it depends on weather condition which needs to be integrated with other energy sources. This is necessary as it may provide opportunity in exceeding the current system performance. 


\section{Fuel cell}

Table 2. Comparison of fuel cell with other power generation system[22].

\begin{tabular}{lccccc} 
& diesel engine & turbine generator & Photovoltaic & Wind turbine & Fuel cell \\
\hline $\begin{array}{l}\text { capacity range } \\
\text { efficiency }\end{array}$ & $500 \mathrm{~kW}-50 \mathrm{MW}$ & $500 \mathrm{~kW}-5 \mathrm{MW}$ & $1 \mathrm{~kW}-1 \mathrm{MW}$ & $10 \mathrm{~kW}-1 \mathrm{MW}$ & $200 \mathrm{~kW}-2 \mathrm{MW}$ \\
$\begin{array}{l}\text { capital cost } \\
(\$ \mathrm{~kW})\end{array}$ & $35 \%$ & $29-42 \%$ & $6-19 \%$ & $25 \%$ & $40-85 \%$ \\
\hline
\end{tabular}

Table 3. Fuel cell types [23].

\begin{tabular}{cccc}
\hline Fuel Cell Type & $\begin{array}{c}\text { Operating } \\
\text { Temperature }\left({ }^{\circ} \mathrm{C}\right)\end{array}$ & $\begin{array}{c}\text { Electrical } \\
\text { Efficiency }(\%)\end{array}$ & $\begin{array}{c}\text { Combined heat and } \\
\text { power efficiency }(\%)\end{array}$ \\
\hline Proton Exchange Membrane & $50-100$ & 58 & 32 \\
Alkaline Fuel Cell & $90-100$ & 60 & 20 \\
Phosporic Acid Fuel Cell & $150-200$ & 39 & 43 \\
Molten Carbonate Fuel Cell & $600-700$ & 44 & 36 \\
Solid Oxide Fuel Cell & $800-1000$ & 42 & 42 \\
\hline
\end{tabular}

consumption and also the carbon dioxide emission. It was

As shown in Table 2, fuel cell has the highest efficiency when compared to other power generation systems.

Fuel cell can be distinguished by the type of electrolyte used and their operating temperature as shown in Table 3. PEMFC operates at the lowest temperature whereas Solid Oxide Fuel Cell at the highest temperature. Generally, higher output can be achieved at higher temperature. Table 3 demonstrates the electrical efficiency and combined heat and power efficiency of various types of fuel cell.

Among all types of fuel cell, PEMFC is found to be the best application for residential and transportation as it operates under low temperature, fast start up, low emission of oxides of nitrogen and sulfur and produce low noise [24]. A study on the feasibility of utilizing PEMFC in residential sector has been carried out by $\mathrm{Oh}$ et.al [25] where a 1-kW PEMFC was installed on an apartment house with average monthly electric consumption of $370 \mathrm{kWh}$. It is showed that $20 \%$ savings can be achieved by PEMFC utilization. To commercialize PEMFC, several technical problems in PEMFC must be solved and one of them is proper thermal management. Heat generation by PEMFC is estimated similar to its electrical efficiency which is about $50 \%$. In order to increase the overall efficiency of PEMFC, this wasted heat generation must be fully utilized. Heat generation of PEMFC is mainly caused by entropic heat of reaction, irreversibilities of the electrochemical reactions and ohmic resistances, as well as water condensation[26].Obara and Tanno[27] carried out a study on $3 \mathrm{~kW}$ PEMFC co-generation system for residential application considering the regional characteristics in Japan. The system performance is evaluated based on exergy flow and exergy efficiency. Obara [28] conducted a study on the efficiency of PEMFC on the low load region in order to maintain the efficiency of the power generation, thus avoiding the high cost. Numerical analysis was done in determining the fuel

\footnotetext{
a Corresponding author: mfirdausb@ump.edu.my
}

found that power generation efficiency was higher at the high load factor value.

PEMFC is potentially suitable in becoming power generation system for residential with its characteristic; fast start up, low temperature, low emission, etc. Consuming hydrogen gas as its fuel makes it sustainable and not reliable on weather condition. The utilization of heat from PEMFC is an important parameter to take into account. Heat efficiency is found to be similar with power efficiency which is about $50 \%$. All of the above features make PEMFC a great system to be integrated with $\mathrm{PV} / \mathrm{T}$ system. As both systems generate electricity and heat simultaneously, study on these two output energy utilization is necessary in optimizing the system performance.

\section{Different hybrid system with photovoltaic and fuel cell}

\subsection{Hybrid PV-FC}

\subsubsection{Hybrid PV-FC-Battery}

In this configuration as shown in Fig.3, photovoltaic is the primary source during daylight and fuel cell act as a backup during the night or when load exceed the output power of photovoltaic. During the peak hours, load demand is totally supported by the photovoltaic and surplus energy is sent to the battery as energy storage. Battery and fuel cell work simultaneously when output power of photovoltaic is zero. Maximum power is extracted from PV panels by using Maximum Power Point Tracker (MPPT). 


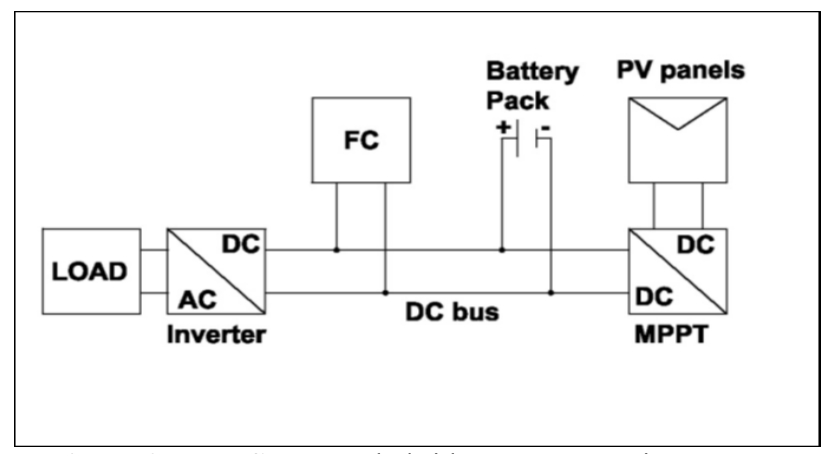

Figure 3. PV-FC-Battery hybrid power generation system layout[29].

Zhang and Huang [30] proposed a fault detection method to diagnose the fault of hybrid systems. The proposed system consists of PV panel, PEMFC, and lithium-ion battery. All the parts are connected to the DC bus. PV system is the primary source while PEMFC will meet the deficient power.

Bruni et.al[29] conducted experimental and numerical study on hybrid PV-FC-Battery to optimize the system by means of rule based control strategy. The control strategy succeeded in increasing the lifetime of components and also cutting down the cost.

Bruni et.al[31] proposed a new novel definition of the energy efficiency in system of integration PV, FC and battery. The new definition is related to the system sizing and the value influenced by the fossil energy consumption.

\subsubsection{Hybrid PV-FC-Battery-Electrolyzer}

This system consists generally of a photovoltaic, electrolyzer, hydrogen storage tank, fuel cell and power conditioning unit. Surplus energy from the photovoltaic will be sent to the electrolyzer for hydrogen production process. Fuel cell will be utilized when Photovoltaic energy is deficient and works as an auxiliary generator.

Gencoglu et.al [32] designed a hybrid system as shown in Figure 4 for total power load demand $6.23 \mathrm{~kW}$. The hybrid system output power is $7.3 \mathrm{~kW}$ with $2.5 \mathrm{~kW}$ from $\mathrm{PV}$ and $4.8 \mathrm{~kW}$ from fuel cell.
Castaneda et.al [33] studied a stand-alone hybrid system which only use a PV as the main source. A new sizing method was proposed and three control strategies were performed for energy management.

\subsubsection{Hybrid PV-FC-Electrolyzer}

In this configuration, as the cost of battery is high, instead of using battery, the surplus energy is totally stored in hydrogen storage tank. Fuel cell acts as a backup during night or when PV power is deficient.

Hwang et.al [34] developed a dynamic model to simulate a stand-alone PV-FC hybrid power systemas shown in Fig.5. In this system, PV is designed to meet the load demand. During the daylight, when there is excess energy from PV, it will be used to produce hydrogen through electrolyzer. During the low radiation period, fuel cell will be the backup system by consuming hydrogen from hydrogen tank.

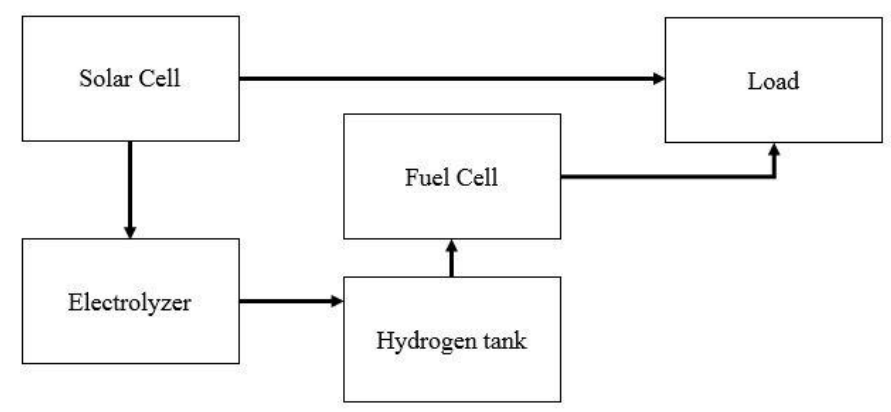

Figure 5. Schematic diagram of PVFC-Electrolyzer hybrid system

El-Shatter et.al [35] designed a hybrid system composed of PV, electrolyzer and fuel cell. A fuzzy regression model (FRM) is utilized to extract maximum power from PV. Tesfahunegn et.al [36]proposed an algorithm to suppress short term power fluctuation in PV generation.

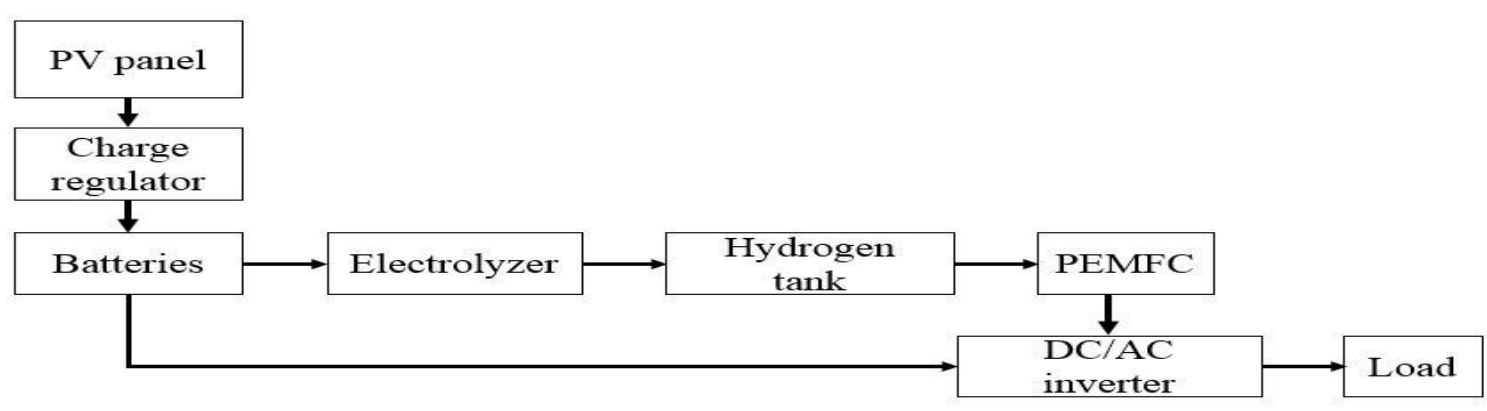

Figure 4. Hybrid PV-FC-Battery-Electrolyzer

\footnotetext{
${ }^{\mathrm{a}}$ Corresponding author: mfirdausb@ump.edu.my
} 


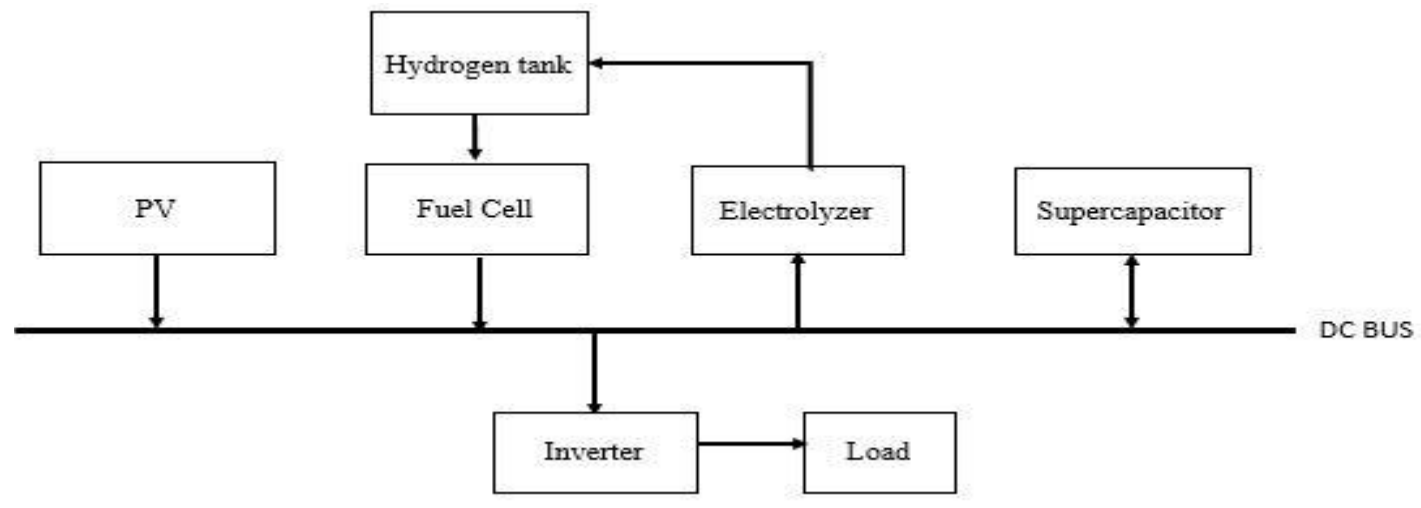

Figure 6. Block diagram of the proposed system

\subsubsection{Hybrid PV-FC-Supercapacitor}

Several hybrid systems utilize super capacitor for storage device due to the slow response of fuel cell. Super capacitor is greater than battery in term of power density. By using super capacitor, fuel cell will not need to support all the load demand, thus, sizing up the fuel cell is unnecessary. This will eventually prevent the gas starvation in fuel that may affect the performance and lifetime.

Uzunoglu et.al[37] proposed a dynamic modeling of hybrid $\mathrm{PV} / \mathrm{FC} / \mathrm{SC}$ as shown in Fig. 6. The system is designed for stand-alone micro grid user application. This modeling can be used for analysing each component as well as analysing the overall system performance and also for the system design.

Thounthong et al[38]designed a mathematical model of hybrid $\mathrm{PV} / \mathrm{FC} / \mathrm{SC}$. A dynamic optimization is proposed using intelligent fuzzy logic controller. Several others proposed the same system with the energy management approach[38,39]

Various configurations have been proposed by previous studies which can be concluded that they can be classified in term of energy storage method. In the early stage a simple system which only consisting of battery is used. Battery is however rapidly degrading and not reliable in long term as well as not economic. This leads to the utilization of electrolyzer and hydrogen storage tank which is more reliable and great in storing higher capacity of energy. Besides that, supercapacitor is also used on several studies for its high power density and long lifetime characteristic.

\subsubsection{Hybrid PV-FC-Wind Turbine (WT)}

Generally, PV and wind turbine are the primary energy sources and FC acts as the backup. The wind turbine is proposed in the system to fully utilize the surround renewable source and to cover the intermittent power of PV.
Ahmed et.al [41]proposed a system with the combination of PV, FC and WT to increase the output power and to generate more constant power. The system is connected to grid to reduce the dependency on the grid system and to provide continuous power supply when the grid system is interrupted.

Mezzani et al[42] investigated the hybrid system consisting of photovoltaic/wind/fuel cell. A mathematical model topology was introduced with the power management of the global system control. The simulation of the proposed system has been done using Matlab/Simulink software.

Wang et al[43] carried out a study on a hybrid energy system which consists of PV, FC, WT, battery and electrolyzer. The PV and wind act as the primary power sources and the FC acts as the backup unit. The battery is used for a short-time backup.

The same configuration is also proposed with the utilization of three individual dc-dc boost converters to manage the power flow to the load[44].

Instead of using PV and FC, several studies have included wind turbine sub system in their configuration to minimize the size of PV and also generate more output power. Furthermore, combination of more sub-system provides more advantage to the system in term of reliability and sustainability aspect.

\subsection{Hybrid PV/T-FC (PEMFC) Co-generation}

Zafar and Dincer[45] proposed a hybrid system consisting of $\mathrm{PV} / \mathrm{T}$ and fuel cell. $\mathrm{PV} / \mathrm{T}$ is the primary source which converts solar energy into electricity and heat. During off peak hours, surplus energy PV is sent to the electrolyzer which then generates hydrogen. Fuel cell generates electricity, heat energy and drinkable water to the residential sector when the load demand exceeds the $\mathrm{PV} / \mathrm{T}$ maximum output power. The study showed that energy and exergy of the overall system increase to $5.65 \%$ and $19.80 \%$ respectively when the heat generation of fuel cell is utilized.

\footnotetext{
a Corresponding author: mfirdausb@ump.edu.my
} 


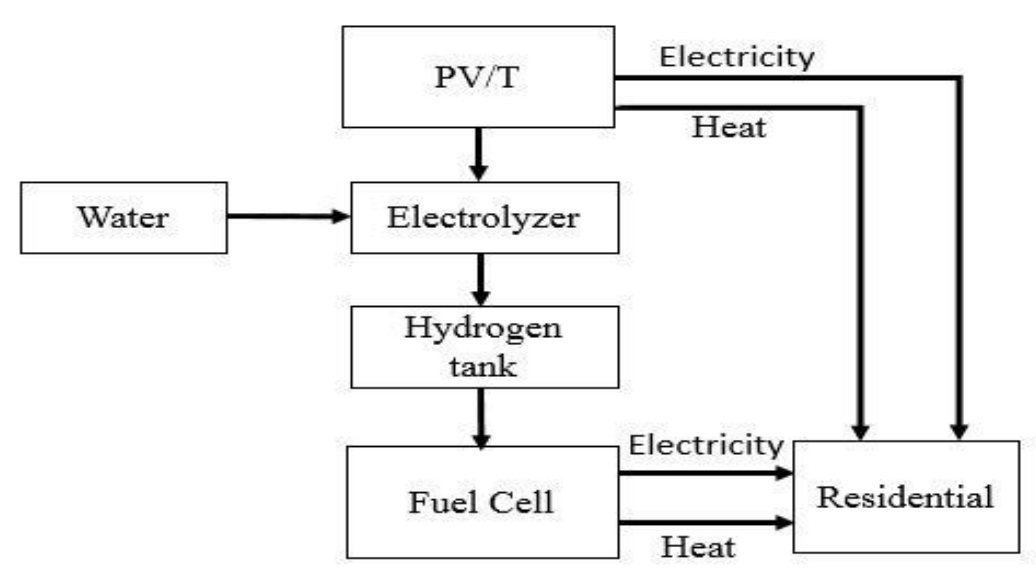

Figure 7. Schematic diagram of the combination PV/T and fuel cell co-generation system

Hosseini et.al [46] studied a combined PV and fuel cell. PV generates electricity for hydrogen production and supply load demand. High temperature gases from the fuel cell stack is flowed to a heat recovery steam generator (HRSG) to produce steam. The HRSG produce steam for the absorption chiller.

Based on previous studies, research on hybrid PV/TPEMFC CGS is still not yet comprehensively explored. Most of the previous studies focus only on the power generation of the hybrid system where the waste heat was not utilized. There is necessary in using the waste heat as it could improve the overall system performance. This hybrid co-generation system can be further studied for several other aspects including operation strategy, optimization of size, and operation algorithm.

\section{Conclusion}

A review on the PV/T system, fuel cell and different type of hybrid system of $\mathrm{PV} / \mathrm{T}$ and fuel cell has been done. The present study helps to understand the important parameters that affect both systems. Besides that, recent developments of the hybrid system of PV/T and fuel cell are also presented to identify the insufficient study in this field. Mass flow rate of $\mathrm{PV} / \mathrm{T}$ was found to affects the system performance as it is an important parameter to decrease the solar cell temperature and also to absorb heat energy efficiently. Various configuration of PV/T-fuel based hybrid can be distinguished by their energy storage method. Mostly used was by storing the energy using electrolyzer and hydrogen tank. Previous studies mostly focus on the power generation where the waste heat was not utilized. Study on PV/T-PEMFC in simultaneous heat and power generation system are indeed necessary and significant for future development. Utilization of heat for combined heat and power (CHP) generation system significantly increases the overall system efficiency compared to single power generation system while improving both economic and environmental performance.

\section{Acknowledgement}

The author would like to acknowledge the authority of Malaysia Ministry of Education and University Malaysia Pahang upon the funding provide for the research under the grant (FGRS/2/2013/TK06/UMP/02/1) or RDU130133.

\section{References}

1. V. C. Güngör, D. Sahin, T. Kocak, S. Ergüt, C. Buccella, C. Cecati, and G. P. Hancke, "Smart grid technologies: Communication technologies and standards," IEEE Trans. Ind. Informatics, vol. 7, no. 4, pp. 529-539, 2011.

2. D. Rekioua, S. Bensmail, and N. Bettar, "Development of hybrid photovoltaic-fuel cell system for stand-alone application," Int. J. Hydrogen Energy, vol. 39, no. 3, pp. 1604-1611, 2014.

3. S. Mekhilef, R. Saidur, and a. Safari, "Comparative study of different fuel cell technologies," Renew. Sustain. Energy Rev., vol. 16, no. 1, pp. 981-989, 2012.

4. a. Larrosa-Guerrero, K. Scott, I. M. Head, F. Mateo, a. Ginesta, and C. Godinez, "Effect of temperature on the performance of microbial fuel cells," Fuel, vol. 89, no. 12, pp. 3985-3994, 2010.

5. W. Schmittinger and A. Vahidi, "A review of the main parameters influencing long-term performance and durability of PEM fuel cells," $J$. Power Sources, vol. 180, no. 1, pp. 1-14, May 2008.

6. F. Sarhaddi, S. Farahat, H. Ajam, a. Behzadmehr, and M. Mahdavi Adeli, "An improved thermal and electrical model for a solar photovoltaic thermal (PV/T) air collector," Appl. Energy, vol. 87, no. 7, pp. 2328-2339, Jul. 2010.

\footnotetext{
a Corresponding author: mfirdausb@ump.edu.my
} 
7. H. Zondag, "Flat-plate PV-Thermal collectors and systems: A review," Renew. Sustain. Energy Rev., vol. 12, no. 4, pp. 891-959, May 2008.

8. P. G. Charalambous, G. G. Maidment, S. a. Kalogirou, and K. Yiakoumetti, "Photovoltaic thermal (PV/T) collectors: A review," Appl. Therm. Eng., vol. 27, no. 2-3, pp. 275-286, Feb. 2007.

9. S. C. Solanki, S. Dubey, and A. Tiwari, "Indoor simulation and testing of photovoltaic thermal (PV/T) air collectors," Appl. Energy, vol. 86, no. 11, pp. 2421-2428, 2009.

10. T. H. Lin, W. C. Hung, and F. S. Sun, "PERFORMANCE EVALUATION OF SOLAR PHOTOVOLTAIC / THERMAL SYSTEMS," vol. 70, no. 5, pp. 443-448, 2001.

11. J. Ji, G. Pei, T. T. Chow, K. Liu, H. He, J. Lu, and C. Han, "Experimental study of photovoltaic solar assisted heat pump system," Sol. Energy, vol. 82, no. 1, pp. 43-52, 2008.

12. K. Moradi, M. Ali Ebadian, and C.-X. Lin, "A review of PV/T technologies: Effects of control parameters," Int. J. Heat Mass Transf., vol. 64, pp. 483-500, Sep. 2013.

13. K. Vats, V. Tomar, and G. N. Tiwari, "Effect of packing factor on the performance of a building integrated semitransparent photovoltaic thermal (BISPVT) system with air duct," Energy Build., vol. 53, pp. 159-165, Oct. 2012.

14. T. T. Chow, W. He, and J. Ji, "Hybrid photovoltaic-thermosyphon water heating system for residential application," Sol. Energy, vol. 80, no. 3, pp. 298-306, Mar. 2006.

15. A. Tiwari and M. S. Sodha, "Performance evaluation of hybrid PV/thermal water/air heating system: A parametric study," Renew. Energy, vol. 31, no. 15, pp. 2460-2474, Dec. 2006.

16. a. Shahsavar and M. Ameri, "Experimental investigation and modeling of a direct-coupled PV/T air collector," Sol. Energy, vol. 84, no. 11, pp. 1938-1958, 2010.

17. A. Ibrahim, M. Y. Othman, M. H. Ruslan, M. A. Alghoul, M. Yahya, A. Zaharim, and K. Sopian, "Performance of Photovoltaic Thermal Collector ( PVT ) With Different Absorbers Design," vol. 5, no. 3, pp. 321-330, 2009.

18. A. Tiwari and M. S. Sodha, "Parametric study of various configurations of hybrid $\mathrm{PV} /$ thermal air collector: Experimental validation of theoretical model," Sol. Energy Mater. Sol. Cells, vol. 91, no. 1, pp. 17-28, Jan. 2007.

19. S. Dubey and G. N. Tiwari, "Analysis of PV/T flat plate water collectors connected in series," Sol. Energy, vol. 83, no. 9, pp. 1485-1498, Sep. 2009.

20. T. T. Chow, "Performance analysis of photovoltaic-thermal collector by explicit dynamic model," Sol. Energy, vol. 75, no. 2, pp. 143-152, Aug. 2003.
21. H. A. Zondag, D. W. De Vries, W. G. J. Van Helden, and R. J. C. Van Zolingen, "T he yield of different combined PV-thermal collector designs," vol. 74, pp. 253-269, 2003.

22. a. Kirubakaran, S. Jain, and R. K. Nema, "A review on fuel cell technologies and power electronic interface," Renew. Sustain. Energy Rev., vol. 13, no. 9, pp. 2430-2440, 2009.

23. K. Rajashekara, "Hybrid fuel-cell strategies for clean power generation," IEEE Trans. Ind. Appl., vol. 41, no. 3, pp. 682-689, 2005.

24. M. Y. El-Sharkh, a. Rahman, M. S. Alam, P. C. Byrne, a. a. Sakla, and T. Thomas, "A dynamic model for a stand-alone PEM fuel cell power plant for residential applications," J. Power Sources, vol. 138, no. 1-2, pp. 199-204, Nov. 2004.

25. S. D. Oh, K. Y. Kim, S. B. Oh, and H. Y. Kwak, "Optimal operation of a 1-kW PEMFC-based CHP system for residential applications," Appl. Energy, vol. 95, pp. 93-101, 2012.

26. S. G. Kandlikar and Z. Lu, "Thermal management issues in a PEMFC stack - A brief review of current status," Appl. Therm. Eng., vol. 29, no. 7, pp. 1276-1280, May 2009.

27. S. Obara and I. Tanno, "Exergy analysis of a regional-distributed PEM fuel cell system," Int. J. Hydrogen Energy, vol. 33, no. 9, pp. 2300-2310, 2008.

28. S. Obara, "CO2 discharge characteristic of PEMFC/hydrogen-gas-engine hybrid cogeneration," Int. J. Hydrogen Energy, vol. 32, no. 7, pp. 819831, 2007.

29. G. Bruni, S. Cordiner, M. Galeotti, V. Mulone, M. Nobile, and V. Rocco, "Control strategy influence on the efficiency of a hybrid photovoltaic-battery-fuel cell system distributed generation system for domestic applications," Energy Procedia, vol. 45, pp. 237-246, 2014.

30. L. Zhang and A. Q. Huang, "Model-based fault detection of hybrid fuel cell and photovoltaic direct current power sources," J. Power Sources, vol. 196, no. 11, pp. 5197-5204, 2011.

31. G. Bruni, S. Cordiner, and V. Mulone, "Domestic distributed power generation: Effect of sizing and energy management strategy on the environmental efficiency of a photovoltaicbattery-fuel cell system," Energy, vol. 77, pp. 133-143, 2014.

32. M. T. Gencoglu and Z. Ural, "Design of a PEM fuel cell system for residential application," Int. J. Hydrogen Energy, vol. 34, no. 12, pp. 52425248, 2009.

33. M. Castañeda, A. Cano, F. Jurado, H. Sánchez, and L. M. Fernández, "Sizing optimization, dynamic modeling and energy management strategies of a stand-alone PV/hydrogen/batterybased hybrid system," Int. J. Hydrogen Energy, vol. 38, no. 10, pp. 3830-3845, 2013.

\footnotetext{
${ }^{\mathrm{a}}$ Corresponding author: mfirdausb@ump.edu.my
} 
34. J. J. Hwang, L. K. Lai, W. Wu, and W. R. Chang, "Dynamic modeling of a photovoltaic hydrogen fuel cell hybrid system," Int. J. Hydrogen Energy, vol. 34, no. 23, pp. 9531-9542, 2009.

35. T. F. El-Shatter, M. N. Eskandar, and M. T. ElHagry, "Hybrid PV/fuel cell system design and simulation," Renew. Energy, vol. 27, no. 3, pp. 479-485, 2002.

36. S. G. Tesfahunegn, Ø. Ulleberg, P. J. S. Vie, and T. M. Undeland, "PV fluctuation balancing using hydrogen storage - A smoothing method for integration of PV generation into the utility grid," Energy Procedia, vol. 12, no. 1876, pp. 10151022, 2011.

37. M. Uzunoglu, O. C. Onar, and M. S. Alam, "Modeling, control and simulation of a PV/FC/UC based hybrid power generation system for stand-alone applications," Renew. Energy, vol. 34, no. 3, pp. 509-520, 2009.

38. P. Thounthong, S. Sikkabut, a. Luksanasakul, P. Koseeyaporn, P. Sethakul, S. Pierfederici, and B. Davat, "Fuzzy logic based DC bus voltage control of a stand alone photovoltaic/fuel cell/supercapacitor power plant," 2012 11th Int. Conf. Environ. Electr. Eng. EEEIC 2012 - Conf. Proc., pp. 725-730, 2012.

39. P. Thounthong, V. Chunkag, P. Sethakul, S. Sikkabut, S. Pierfederici, and B. Davat, "Energy management of fuel cell/solar cell/supercapacitor hybrid power source," J. Power Sources, vol. 196, no. 1, pp. 313-324, 2011.

40. P. Thounthong, A. Luksanasakul, P. Koseeyaporn, and B. Davat, "Intelligent modelbased control of a standalone photovoltaic/fuel cell power plant with supercapacitor energy storage," IEEE Trans. Sustain. Energy, vol. 4, no. 1, pp. 240-249, 2013.

41. N. a. Ahmed, a. K. Al-Othman, and M. R. Alrashidi, "Development of an efficient utility interactive combined wind/photovoltaic/fuel cell power system with MPPT and DC bus voltage regulation," Electr. Power Syst. Res., vol. 81, no. 5, pp. 1096-1106, 2011.

42. N. Mezzai, D. Rekioua, T. Rekioua, a. Mohammedi, K. Idjdarane, and S. Bacha, "Modeling of hybrid photovoltaic/wind/fuel cells power system," Int. J. Hydrogen Energy, vol. 39, no. 27 , pp. 15158-15168, 2014.

43. C. Wang, S. Member, and M. H. Nehrir, "Power Management of a Stand-Alone Wind / Photovoltaic / Fuel Cell Energy System," vol. 23, no. 3, pp. 957-967, 2008.

44. N. a. Ahmed, M. Miyatake, and a. K. Al-Othman, "Power fluctuations suppression of stand-alone hybrid generation combining solar photovoltaic/wind turbine and fuel cell systems," Energy Convers. Manag., vol. 49, no. 10, pp. 2711-2719, 2008.

45. S. Zafar and I. Dincer, "Thermodynamic analysis of a combined PV/T-fuel cell system for power,

a Corresponding author: mfirdausb@ump.edu.my heat, fresh water and hydrogen production," Int. J. Hydrogen Energy, vol. 39, no. 19, pp. 99629972, 2014.

46. M. Hosseini, I. Dincer, and M. a. Rosen, "Hybrid solar-fuel cell combined heat and power systems for residential applications: Energy and exergy analyses," J. Power Sources, vol. 221, pp. 372380, 2013.

1. Luigi T.De Luca, Propulsion physics (EDP Sciences, Les Ulis, 2009)

2. F. De Lillo, F. Cecconi, G. Lacorata, A. Vulpiani, EPL, 84 (2008) 